\section{Correct interpretations of the vitalographs}

Figure 1: normal subject

Figure 2: subject with a restrictive defect

Figure 3: subject with a combined defect

Figure 4: normal subject

Figure 5: subject with an obstructive defect

Box 2

because of inconsistency of efforts by patients. ${ }^{4}$ High quality spirometric tests require accurate equipment, good test procedures, an ongoing programme of quality control, appropriate reference values and good algorithms for

1 Crapo RO. Pulmonary function testing. $N$ Engl $f$ Med 1994;331:25-30

2 Russell NJ, Crichton NJ, Emmerson PA, Morgan AD. Quantitative assessment of the value of spirometry. Thorax 1986;41:360-3. interpretation of results. ${ }^{1}$ Because of this potential for 'noise', doctors need to be able to assess accurately the quality of the vitalograph recording and its interpretation. Ongoing education for doctors of all grades would help. In addition, a report by the respiratory technician and/or respiratory physician, or computer analysis if available, would improve the service for patients. This would not negate the responsibility of the doctor who must still check the results. However, if there were a discrepancy between the report and the doctor's interpretation, the doctor would be aware of a problem and could seek further guidance.

We would like to thank Mr John Verdin, Head Technician, and Dr John Delaney, Respiratory Consultant, Wirral NHS Trust Hospital and Dr GJ Williams, Halton NHS Trust Hospital, for their help and support.

3 Gentry SE, Hodge RH, Kaiser D, Walker FB, Suratt PM Pulmonary function testing in a general medical practice. $f$ Commun Health 1983;8:263-8.

4 Becklake MR. Concepts of normality applied to the measurement of lung function. Am $\mathcal{F}$ Med 1986;80:1158-64.

Walter Reed (1851-1902) was born at Gloucester, Virginia, USA, son of a Methodist minister. He graduated MD from the University of Virginia, Charlottesville (1869), became a doctor in the US Army, and eventually Professor of Bacteriology in the Army Medical College, Washington DC. He will be remembered primarily for bringing yellow fever under control. He died on 23 November 1902 from amoebic dysentery contracted in Cuba. - D G fames 